\title{
Female Directors And Firm Characteristics: A USA - UK Comparison
}

Annette Hebble, (E-mail: hebble@stthom.edu), University of St. Thomas

\begin{abstract}
Shareholders and other stakeholders are placing an increasing emphasis on corporate governance. The composition of a board is an important aspect of corporate governance. There is some evidence that gender diversity in the boardroom has an impact on the operations of a company. Both U.S. and UK corporations are increasing female representation on their boards. The purpose of this particular study is to compare gender diversity on U.S. and UK boards, and investigate some firm characteristics that may be associated with above or below average female representation.
\end{abstract}

\section{INTRODUCTION}

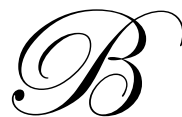

oth the business and investment community have long debated the legitimacy of the connection between corporate governance practices and financial performance. Nonetheless, it has become increasingly accepted that the corporate objective of maximizing shareholder value requires not only superior financial performance, but also attention to a variety of governance issues, including board diversity.

Shareholders and other stakeholders are placing an increasing emphasis on governance. The composition of a board is an important aspect of corporate governance. Members of a corporate board shape strategy and outline company guidelines. An increasing number of corporations appoint individuals with varying expertise, views and backgrounds to their board of directors. This trend is apparent at large public corporations in the U.S. and many other countries such as the UK.

Shareholders are demanding that different viewpoints are heard. A director's views are influenced by personal characteristics and experiences. Consequently, diversity brings a wider perspective and original ideas to the board as a whole, which in turn may improve corporate practices. Improved corporate practices may lead to superior financial performance.

\section{FEMALE REPRESENTATION IN THE BOARD ROOM}

Women's under-representation on corporate boards is inconsistent with the role women play in the U.S. and U.K. labor markets. Additionally, the past decade's lapses in corporate governance and failures in leadership is an indication that public companies cannot afford to ignore a large untapped pool of talent and independent perspective presented by accomplished women (Board of Directors Network, November 26, 2004).

Though women are making strides in the boardroom, 54 of the Fortune 500 companies have no female board members, and 208 other firms have only one female director, according to a new report (June 18, 2004). In all, women held 13.6 percent of Fortune 500 board seats in 2003, up from 9.5 percent in 1995 according to Catalyst, a nonprofit research and advocacy organization (BSR, 2005).

In the UK, one in seven directors is a woman, compared with just one in 10 five years ago (Humphreys, 2004). The Chartered Management Institute (CMI) also reports that the proportion of female board directors is also on the increase across all sectors, but does not commensurate with their success in some fields such as IT where women have made significan inroads (CMI). 


\section{PRIOR RESEARCH}

A rush of corporate scandals has led to a re-examination of governance issues such as board composition and financial success since the two appears to be related. Both academic studies and research by business and advocacy groups abound.

A study by Hillman et al. (2002) establishes a relationship between ethnic and gender diversity on corporate boards and superior stock performance. Another empirical study by Carter et al. (2002) shows a relation ship between board diversity and value of Fortune 1000 firms. Erhardt et al. (2003) also note a relationship between diversity of the board and financial performance in their study.

Research also conveys that boards with female representation show some different characteristics. Adams et al. (2004) show that firms with more diverse boards hold more board meetings. The same study also indicates that women have fewer problems attending board meetings. Business for Social Responsibility (BSR) reports that a study by the Conference Board of Canada states that 94 percent of boards with three or more women demanded conflict-ofinterest guidelines, compared with 58 percent of boards without female representation. . Also, 72 percent of boards with two or more women carried out formal board-performance evaluations, compared with 49 percent of boards without female representation.

Further, BSR reports that the same arguments for board diversity are made on both sides of the Atlantic Ocean. For example, General Motors Guidelines on Significant Corporate Governance Issues discusses the appropriate skills and characteristics required of Board members. An assessment should include issues of judgment, diversity, age, skills such as understanding of manufacturing technologies, international background, etc. (Guidelines: 1). The 1998 British Hampel Report on Corporate Governance makes similar statements. Companies should recruit directors from a greater diversity of backgrounds. Diversity is not favored for its own sake, to give a politically correct appearance to the list of board members or to represent stakeholders, but that a diverse board can make a real contribution on the board (Role of Directors: III. B. 3.15).

Two Scandinavian countries are taking board diversity one step further by mandating larger female representation on the boards. Norway is striving for 40 percent female representation, while Sweden is aiming for 25 percent by the end of 2005 .

Corporate governance not only receives attention from researchers and the companies themselves. Agencies are popping up and offering proprietary ratings of corporate governance and board composition. Studies that are correlating various aspects of corporate governance and financial rewards are becoming more and more common. Identifying the characteristics of these companies may help investors and stakeholders to understand the relationship between corporate governance issues such as board composition and financial success, whether in accounting terms or stock market prices.

Similar trends are evident both in the U.S. and the UK, so a comparison of corporate financial characteristics between the two countries, with and without female board representation deserves further empirical investigation. The emphasis of this study is on the correlation of female representation on a corporate board and characteristics in terms of size, profitability and risk.

\section{SAMPLE SELECTION}

Since public companies in both the U.S. and the UK appear to be on a similar quest to increase female representation on public boards, identifying common characteristics could be useful. I obtained a list of the S\&P 100 companies and a list of FTSE 100 companies. Both of these lists are comprised of large corporations. Further, I obtained information about the total number of directors and female representation for those companies for year 2003. Information for the U.S. companies was provided by the Corporate Library, an independent research firm that maintains corporate governance data for more than 2,000 U.S. companies. Information about the size of the boards and female representation for UK companies were found in the Female FTSE Report 2003.

The financial data 
for the companies is obtained from Mergent Online. Specifically, data is collected for year 2003 relating to size, profitability and risk. From the companies with complete data, a random sample of 30 U.S. companies and 30 UK companies is analyzed.

\section{DATA ANALYSIS AND FINDINGS}

U.S. companies have a higher representation of female board members to total board members than those in the UK. The ratio of female directors is twice as high for the U.S. The thirty U.S. companies in the sample have 351 directors in total and 58 are women. The corresponding numbers for the UK are 367 and 30 . Only one U.S. company and ten UK companies have no female directors on their boards. Out of the 11 companies that have no female directors, eight are ranked in the bottom quartile by revenues, two companies in the third quartile and only one company in the second quartile. Table 1 shows board composition and provides some additional descriptive statistics about board size and female representation by country.

Financial information for the UK companies is expressed in U.S. currency. Table 2 shows the financial variables examined by country. Overall, U.S. companies in the sample are larger and more profitable than their UK counterparts. Table 3 is interesting in that it shows the same variables as Table 2, but the categories are above average female representation or below average on corporate boards. Above average female representation for purposes of this table is defined ad having a ratio of female directors to total directors above the median. The data in this table indicates that companies with above female representation on the board are larger and more profitable, regardless of whether the company is American or British.

Total assets, revenues, and equity are used to measure size. For profitability, net income, return on assets (ROA) and return on equity (ROE) are examined. For the third category risk, debt to total assets, long-term debt to equity, and current ratio are used for measurement purposes. Pearson correlations are used to identify associations between the percentage of female board members to total board members and major firm characteristics of size, profitability and risk. Table 4 shows the $\mathrm{R}$ squared and P-values for the correlations with female presence on the boards.

Our investigation of the full sample indicates that asset size is significant, i.e. there is a difference between those companies with female representation. Total revenues and equity all show significant results. On the other hand, total asset is not a significant variable.

Two of the three profitability measures are also significant, i.e. net income and ROA. U.S. and UK GAAP rules differ, so some caution is warranted in interpreting the results. For the third measure risk, only the current ratio is significant.

\section{CONCLUDING REMARKS}

Large successful multinationals are not only utilizing their financial resources well, but also value human capital. Diversity on the board leads to different opinions being aired as part of the decision making process. It appears that U.S. and UK companies are similar in this respect. This is an interesting finding given the current quest for board diversity and globalization.

Just like in a number of prior studies, a variation of the relationship between board diversity and financial success is probed. However, this study also attempts to make a comparison between two countries that have similar aims in this area. The results are consistent with prior studies that show that some measures of size and profitability are correlated with board diversity. It is not surprising that these relationships are again verified for public companies that are putting forth a serious effort to show improved corporate governance.

This information provides some interesting insights and provides ideas for refining the research in this area. Much investigation is still needed to probe the nature of the relationships and causality between board diversity and financial characteristics and performance. 
Table 1

Composition Of Boards

\section{Female Directors}

\begin{tabular}{|c|c|c|c|c|c|}
\hline \multicolumn{6}{|c|}{ Female Directors } \\
\hline & Mean & SE Mean & St Dev & Minimum & Maximum \\
\hline U.S. & 1.933 & 0.203 & 1.112 & 0 & 6 \\
\hline UK & 1.000 & 0.173 & 0.947 & 0 & 4 \\
\hline \multicolumn{6}{|c|}{ Total Directors } \\
\hline U.S. & 11.700 & 0.492 & 2.693 & 9 & 21 \\
\hline UK & 12.233 & 0.481 & 2.635 & 8 & 18 \\
\hline \multicolumn{6}{|c|}{ Females As Percentage Of Total Directors } \\
\hline U.S. & 0.165 & 0.0149 & 0.0817 & 0 & 0.3333 \\
\hline UK & 0.081 & 0.0143 & 0.0782 & 0 & 0.3077 \\
\hline
\end{tabular}

Table 2

Average Values Of Variables By Country

\begin{tabular}{|c|c|c|c|}
\hline & \multicolumn{3}{|c|}{ Size } \\
\hline Country & Total Assets & Revenues & Equity \\
\hline U.S. & $103,064,000,000$ & $31,849,837,400$ & $19,071,094,667$ \\
\hline \multirow[t]{3}{*}{$\mathrm{UK}$} & $99,705,179,603$ & $14,597,233,331$ & $8,931,513,235$ \\
\hline & \multicolumn{3}{|c|}{ Profitability } \\
\hline & Net income & ROA & ROE \\
\hline U.S. & $3,568,747,433$ & 6.840 & 26.901 \\
\hline \multirow[t]{3}{*}{ UK } & $1,407,978,195$ & 5.030 & 0.975 \\
\hline & \multicolumn{3}{|c|}{ Risk } \\
\hline & Debt/Total Assets & LT Debt/Equity & Current Ratio \\
\hline U.S. & 0.230 & .507 & 1.437 \\
\hline UK & 0.219 & .686 & 0.975 \\
\hline
\end{tabular}

Table 3

Average Values Of Variables By Female Representation On The Board

\begin{tabular}{|c|c|c|c|}
\hline & \multicolumn{3}{|c|}{ Size } \\
\hline No. of Female Diectors & Total Assets & Revenues & Equity \\
\hline Above Average & $65,286,029,922$ & $31,397,639,749$ & $17,555,516,115$ \\
\hline \multirow[t]{3}{*}{ Below Average } & $132,971,000,000$ & $16,071,194,031$ & $11,160,868,397$ \\
\hline & \multicolumn{3}{|c|}{ Profitability } \\
\hline & Net income & $\mathrm{ROA}$ & ROE \\
\hline Above Average & $3,443,511,505$ & 7.644 & 20.65 \\
\hline \multirow[t]{3}{*}{ Below Average } & $1,652,607,710$ & 4.44 & 12.59 \\
\hline & \multicolumn{3}{|c|}{ Risk } \\
\hline & Debt/Total Assets & LT Debt/Equity & Current Ratio \\
\hline Above Average & 0.2033 & 0.927 & 1.441 \\
\hline Below Average & 0.2419 & 0.327 & 1.001 \\
\hline
\end{tabular}


Table 4

Correlation Of Percentage Of Female Board Members To Size, Profitability And Risk Measures

\begin{tabular}{|c|c|c|c|}
\hline & \multicolumn{3}{|c|}{ Size } \\
\hline & Revenues & Assets & Equity \\
\hline Pearson Correlation & 0.291 & -0.093 & 0.221 \\
\hline P-Value & 0.024 & 0.481 & 0.082 \\
\hline & \multicolumn{3}{|c|}{ Profitability } \\
\hline & Ret Income & ROA & ROE \\
\hline Pearson Correlation & 0.310 & 0.309 & 0.111 \\
\hline P-Value & 0.016 & 0.016 & 0.401 \\
\hline & \multicolumn{3}{|c|}{ Risk } \\
\hline Pearson Correlation & Debt/Total Assets & LT Debt/Equity & Current Ratio \\
\hline P-Value & -0.123 & 0.027 & 0.323 \\
\hline
\end{tabular}

Table 5

U.S.Companies

Correlation Of Percentage Of Female Board Members To Size, Profitability And Risk Measures

\begin{tabular}{|c|c|c|c|}
\hline & \multicolumn{3}{|c|}{ Size } \\
\hline & Revenues & Assets & Equity \\
\hline Pearson Correlation & 0.200 & 0.235 & 0.137 \\
\hline P-Value & 0.290 & 0.211 & 0.469 \\
\hline & \multicolumn{3}{|c|}{ Profitability } \\
\hline & Net Income & ROA & ROE \\
\hline Pearson Correlation & 0.298 & 0.303 & 0.115 \\
\hline P-Value & 0.110 & 0.104 & 0.544 \\
\hline & \multicolumn{3}{|c|}{ Risk } \\
\hline Pearson Correlation & Debt/Total Assets & LT Debt/Equity & Current Ratio \\
\hline P-Value & 0.116 & 0.096 & 0.359 \\
\hline
\end{tabular}

Table 6

UK Companies

Correlation Of Percentage Of Female Board Members Tosize, Profitability And Risk Measures

\begin{tabular}{|c|c|c|c|}
\hline & \multicolumn{3}{|c|}{ Size } \\
\hline & Revenues & Assets & Equity \\
\hline Pearson Correlation & 0.0304 & 0.030 & 0.135 \\
\hline P-Value & 0.102 & 0.875 & 0.485 \\
\hline & \multicolumn{3}{|c|}{ Profitability } \\
\hline & Net Income & ROA & ROE \\
\hline Pearson Correlation & 0.250 & 0.214 & 0.054 \\
\hline P-Value & 0.183 & 0.257 & 0.781 \\
\hline & \multicolumn{3}{|c|}{ Risk } \\
\hline Pearson Correlation & Debt/Total Assets & LT Debt/Equity & Current Ratio \\
\hline P-Value & -0.195 & -0.004 & -.013 \\
\hline
\end{tabular}




\section{REFERENCES}

1. Adams, R., Ferreira, D. (November 2004) Gender Diversity in the Boardroom. ECGI - Finance Working Paper No. 57/2004. 〈http://ssrn.com/abstract=594506 >

2. Business for Social Responsibility (BSR), 2005.

<http://www.bsr.org/CSRResources/IssueBriefDetail.cfm?DocumentID=443>

3. Carter, D., Simkins, B., Simpson G., (2003) Corporate Governance, Board Diversity, and Firm Value, The Financial Review, Vol. 38, 33-53.

4. Corporate Library, (2003). < http://www.thecorporatelibrary.com>

5. $\quad$ Downey, K., Survey Finds Few Female Directors, Washington Post, Friday, June 18, 2004; Page E03.

6. Erhardt, N., Werbel, J., Shrader, C. (2003) Board of Director Diversity and Firm Financial Performance, Corporate Governance: An International Review, 11:2 102.

7. Hillman,A., Harris, A., Cannella Jr., A., (2002), Women and Racial Minorities in Boardroom: How Do Directors Differ?, Journal of Management, 28, 6:747-763.

8. $\quad$ Humphreys, K., What Women Want, PC Magazine, October 18, 2004. $<$ http://www.pcmag.co.uk/analysis/1158811), saved 05202005.

9. Hymowitz, C., Corporate Boards Lack Gender, Racial Equality, CareerJournal. Com, saved May 25, 2005. 〈http://www.careerjournal.com/columnists/inthelead/20030709-inthelead.html >

10. Mergent Online. 2003. Library, University of St. Thomas, Houston, TX, April 2005. $\langle$ http://www.mergentonline.com/compsearch.asp >

11. Gero Communications, Women Under-Represented in Corporate Board Rooms, New National Network Reports Findings from Around U.S, November 26, 2004. <file:///C:/rESEARCH/GRI\%20and\%20Diversity/Board\%20of\%20Directors\%20Network,\%20Inc\%20saved $\% 205012005 . \mathrm{htm}>$

12. Singh, V., Vinnicombe, S., The Female FTSE Report 2003, Cranfield School of Management. 〈http://www.som.cranfield.ac.uk/som/research/centres/cdwbl/projects.asp > 